\title{
Living in Mosul during the time of ISIS and the military liberation: results from a 40-cluster household survey
}

\author{
R. Lafta ${ }^{1}$, V. Cetorelli ${ }^{2}$ and G. Burnham ${ }^{3 *}$ (I)
}

\begin{abstract}
Background: In June 2014, an estimated 1500 fighters of the Islamic State of Iraq and Syria (ISIS) seized control of Mosul, Iraq's second city. Although many residents fled, others stayed behind, enduring the restrictive civil and social policies of ISIS. In December 2016, the military activity, known as the liberation campaign, began in east Mosul, concluding in west Mosul in June 2017.
\end{abstract}

Methods: To assess life in Mosul under ISIS, and the consequences of the military campaign to retake Mosul we conducted a 40 cluster-30 household survey in Mosul, starting in March 2017. All households included were present in Mosul throughout the entire time of ISIS control and military action.

Results: In June 2014, 915 of 1139 school-age children (80.3\%) had been in school, but only 28 (2.2\%) attended at least some school after ISIS seized control. This represented a decision of families. Injuries to women resulting from intimate partner violence were reported in 415 (34.5\%) households. In the surveyed households, 819 marriages had occurred; 688 (84.0\%) among women. Of these women, 89 (12.9\%) were aged 15 years and less, and 253 (49.7\%) were aged under 18 at the time of marriage. With Mosul economically damaged by ISIS control and physically during the Iraqi military action, there was little employment at the time of the survey, and few persons were bringing cash into households. The liberation of Mosul in 2017 caused extensive damage to dwellings. Overall only a quarter of dwellings had not sustained some damage. In west Mosul, only $21.7 \%$ of houses had little or no damage from the conflict, with 98 (21.7\%) households reporting their house had been destroyed, forcing its occupants to move. No houses had regular electricity and there was limited piped water. Inadequate fuel for cooking was reported by 996 (82.9\%) households.

Conclusion: The physical, and social damage occurring during ISIS occupation of Mosul and during the subsequent military action (liberation) was substantial and its impact is unlikely to be erased soon.

Keywords: Mosul, Iraq, War, ISIS, Early marriage

\section{Background}

An estimated 1500 fighters of the Islamic State of Iraq and Syria (ISIS) seized Mosul in June 2014. While many people fled from Mosul, others entered from towns to the north of the city $[1,2]$. The population remaining in Mosul under ISIS control was thought to be about 1.5 million [3]. A caliphate was established with a repressive bureaucracy to manage city affairs and control the life of

\footnotetext{
* Correspondence: gburnha1@jhu.edu

${ }^{3}$ Department of International Health, The Johns Hopkins Bloomberg School

of Public Health, 615 N Wolfe Street, Baltimore, MD 21205, USA

Full list of author information is available at the end of the article
}

its citizens $[4,5]$. The Hesba morality police were created to ruthlessly enforce ISIS edicts.

Many public employees, including teachers and health workers, continued working under ISIS, while other persons were hired to replace persons who fled. Pay for these positions steadily deteriorated, yet people were expected to show up for work [6]. The Iraq Central government continued paying salaries of some civil servants into early 2015 , though ISIS reportedly garnished $20-30 \%$ of these payments [7]. Payment of government pensions continued throughout the time. ISIS looted the Mosul banks, crushed enterprises and forcefully collected money from

(C) The Author(s). 2018 Open Access This article is distributed under the terms of the Creative Commons Attribution 4.0 International License (http://creativecommons.org/licenses/by/4.0/), which permits unrestricted use, distribution, and 
business owners and farmers to finance military campaigns. Many businesses collapsed and unemployment was widespread. Factories were dismantled and machinery sold in neighboring countries [2]. ISIS derived additional income sources from the sale of antiquities, increases in taxation and various financial penalties.

Educational curricula, from primary school to university, were rewritten to support ISIS' radical views $[8,9]$. Young women were at risk of forced marriages to ISIS fighters. At the university of Mosul, subjects such as law, arts and philosophy were dropped. Women could not study engineering and the sciences. Students in some technical courses and at university began to drift away, as they saw no future.

The military campaign to drive ISIS from Mosul, known as the liberaton, began on October 17, 2016. The attack on towns to the east of Mosul hearlded the beginning of the largest urban conflict since WWII [10]. Iraqi forces entered east Mosul on November 1, and declared it liberated on January 24, 2017. The second part of the campaign began with the attack on west Mosul on February 19, 2017. Military progress was slow, particulary in the old city, with widescale damage from artillary, IRAMs (Improvised Rocket Assisted Munitions) and airstrikes which obliterated whole neighborhoods. Fighting in west Mosul was concluded on June 29, 2017.

To assess living circumstances during the ISIS occupation of Mosul and the impact of the military liberation of Mosul on households, this study was undertaken when hostilities ceased.

\section{Methods}

This survey was conducted as soon as security would allow after the major military activity against ISIS had ceased in Mosul. Data were collected through a two-stage 40 cluster survey, with 30 households per cluster. Clusters were located randomly in selected administrative units, designated here as "neighborhoods" (Fig. 1). Based on the pre-ISIS population distribution of Mosul, 15 neighborhoods on the west side of the Tigris were chosen and 25 on the east side. There were no data available on population distribution in Mosul during ISIS occupation. Each neighborhood contained about $200-400$ dwellings. A satellite image of survey site 15 is shown in Fig. 2. For a selected neighborhood, a $10 \mathrm{~m}$ grid was overlaid on a satellite image. A random location was selected. This was marked on the map which was transmitted to the study team along with the coordinates for this location. The survey team identified this location on the ground and selected the nearest dwelling as the start house. From the start house the teams moved to the nearest dwelling to the right until data from 30 households had been collected. When an intersection was reached, the teams always crossed to the right to continue until 30 household

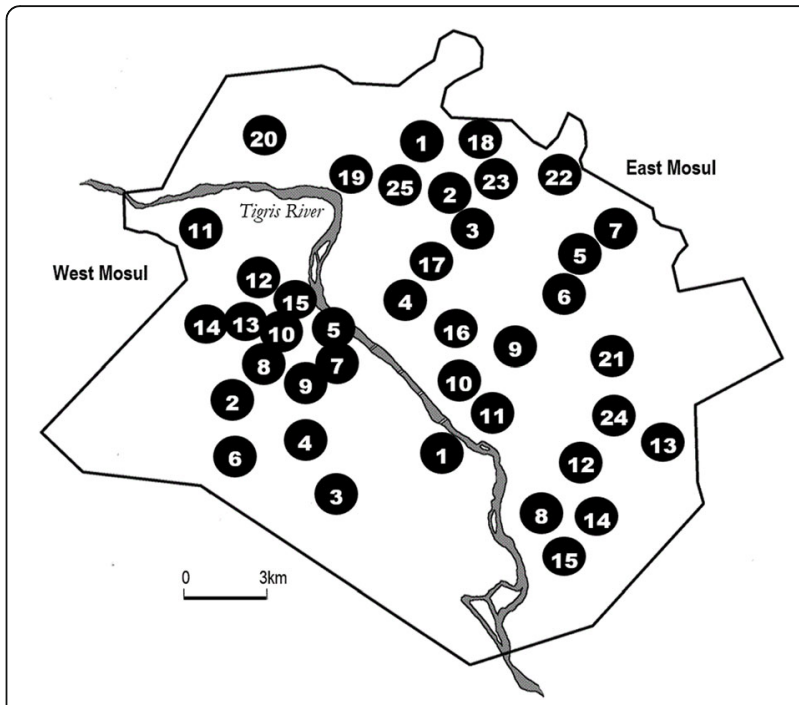

Fig. 1 Location of clusters sampled in Mosul

has been interviewed. For the survey, a household was defined as a group of people eating out of a common kitchen and in a dwelling with a separate entrance from the street, a definition which has proved satisfactory in previous Iraq household surveys [11]. The number of destroyed or unoccupied households in each health cluster was recorded. The survey questionnaire was based on those used in previous Iraq household surveys but adapted for Mosul circumstances. Adaptation was carried out with the assistance of Mosul health workers and faculty at Al Mustansiriya University. The questionnaire contained questions on living conditions, health needs, injuries and deaths. The final format was agreed among all the authors. The sample size of 1200 households was chosen as a size manageable by the number of qualified interviewers available, and utilizing experience from previous Iraq surveys, would provide sufficient details about household indicators. Results concerning health seeking behavior, injuries and deaths are being reported elsewhere.

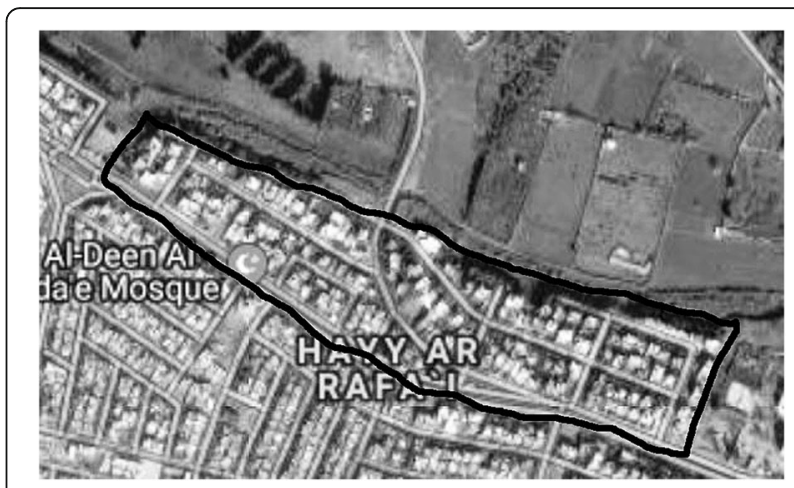

Fig. 2 Satellite image of neighborhood 15, Hay Al Najar. Map data @2018 Google Imagery 
Interviews were carried out by two teams, each with two interviewers who were Mosul physicians with doctorates in community medicine. Three of the four interviewers were female. Training was carried out for two days in Baghdad, and the questionnaire field tested in a non-survey area of Mosul. Only households which had been continuously present in Mosul since June 2014 were included. Verbal consent for the household to participate was obtained from the head of household. The informant was the senior female in the household, as the person most knowledgeable about household issues. No attempt was made to identify former ISIS supporters. Household interviews required about one hour and were conducted in privacy. Plans were made for interviewer protection including safe houses of their relatives and maintaining continuing cell phone communications.

The 25 clusters in east Mosul were surveyed between March 13 and 31, 2017. The prolonged fighting delayed the survey in west Mosul. Once access to west Mosul was gained, a new sampling frame was created to exclude the destroyed and depopulated neighborhoods of west Mosul. The 15 clusters of west Mosul were surveyed between July 18 and 31, 2017.

Five reserve neighborhoods were randomly chosen each for east and for west Mosul, should the original sites not be accessible. None were needed for east Mosul. For west Mosul two were randomly selected as replacements; one because of insecurity and the second to replace a neighborhood which was largely unoccupied.

The data were computer entered in Baghdad, with analysis carried out in Baghdad and Baltimore. Statistical analysis used Stata version 15 (Stata Corp, College Station, TX).

The study received ethical approval from the scientific and technical committee of Al Mustansiriya University, Baghdad. The analysis of deidentified data was exempted by the Institutional Review Board at Johns Hopkins Bloomberg School of Public Health as not human subjects research.

\section{Results}

\section{Demographic information}

Data from 1202 households were collected; 751 in east Mosul, and 451 in west Mosul. This represented a total of 7559 persons, 4867 living in east Mosul and 2692 in west Mosul. There were 2635 children under the age of 15 and 1643 women of child bearing age (Table 1 ). The average household size was 6.5 persons in east Mosul and 6.0 in west Mosul. No household declined to participate.

\section{Education}

Education level of the household members (Table 2) listed only 167 (2.7\%) Mosul household members with
Table 1 Demographic characteristics of surveyed households

\begin{tabular}{|c|c|c|c|c|c|c|}
\hline & \multicolumn{2}{|c|}{ East Mosul } & \multicolumn{2}{|c|}{ West Mosul } & \multicolumn{2}{|c|}{ All Mosul } \\
\hline & No. & $\%$ & No. & $\%$ & No. & $\%$ \\
\hline Young children (0-4 years) & 632 & 13.0 & 353 & 13.1 & 985 & 13.0 \\
\hline Older children (5-14 years) & 1071 & 22.0 & 579 & 21.5 & 1650 & 21.8 \\
\hline Male adults (15-49 years) & 1172 & 24.1 & 650 & 24.1 & 1822 & 24.1 \\
\hline Female adults (15-49 years) & 1126 & 23.1 & 517 & 19.2 & 1643 & 21.7 \\
\hline Older adults (50+ years) & 866 & 17.8 & 593 & 22.0 & 1459 & 19.3 \\
\hline Total & 4867 & 100.0 & 2692 & 100.0 & 7559 & 100.0 \\
\hline
\end{tabular}

no formal education. There were 2089 (33.6\%) who were of school age (6 and older), and ordinarily would have been expected to have been in school. Among residents in the survey, $2670(42.9 \%)$ had completed secondary school or above. In the 1202 households there were 915 (80.3\%) children in school in June 2014. Following the ISIS take over, only 28 children $(2.2 \%)$ had attended school at least at some point, but the majority of families decided to keep school aged children at home.

Table 2 Education levels of household members and school attendance of children

\begin{tabular}{|c|c|c|c|c|c|c|}
\hline & \multicolumn{2}{|c|}{ East Mosul } & \multicolumn{2}{|c|}{ West Mosul } & \multicolumn{2}{|l|}{ Total } \\
\hline & No. & $\%$ & No. & $\%$ & No. & $\%$ \\
\hline \multicolumn{7}{|c|}{ Education level of household members $^{a}$} \\
\hline Adult with none & 97 & 2.0 & 70 & 2.6 & 167 & 2.2 \\
\hline Under age for school ${ }^{\mathrm{a}}$ & 964 & 17.8 & 472 & 17.5 & 1339 & 17.7 \\
\hline School age ${ }^{a}$ & 1383 & 28.4 & 706 & 26.2 & 2089 & 27.6 \\
\hline Primary school & 911 & 18.7 & 383 & 14.2 & 1294 & 17.1 \\
\hline Secondary school & 1020 & 21.0 & 736 & 27.3 & 1756 & 23.2 \\
\hline Post-secondary school & 589 & 12.1 & 325 & 12.1 & 914 & 12.1 \\
\hline
\end{tabular}

Education of children ${ }^{\mathrm{a}}$

In school in up to June 2014?

$\begin{array}{lllllll}\text { Yes } & 304 & 67.4 & 611 & 88.8 & 915 & 80.3 \\ \text { No } & 147 & 32.6 & 77 & 11.2 & 224 & 19.7\end{array}$

Attended school after June 2014?

$\begin{array}{lllllll}\text { Yes } & 3 & 0.5 & 6 & 2.0 & 9 & 0.1 \\ \text { No } & 591 & 96.4 & 300 & 98.0 & 891 & 97.0 \\ \text { Some } & 19 & 3.1 & - & - & 19 & 2.1 \\ \text { Reason not in school? } & & & & & & \\ \text { School closed } & 4 & 0.7 & - & - & - & - \\ \text { Family decided } & 593 & 96.7 & 300 & 99.3 & 893 & 98.0 \\ \text { Taught at home } & 5 & 0.8 & 2 & 0.7 & 7 & 0.7 \\ \text { Left Mosul } & 10 & 1.6 & - & - & 10 & 1.1 \\ \text { Other } & 1 & 0.2 & - & - & 1 & 0.1\end{array}$

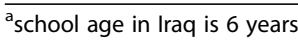




\section{Household relationships}

Since June 2014, there were 819 household members who were reported to have married (Table 3). Of these, $688(84.0 \%)$ were females. The age of marriage was 15 years of less for $89(12.9 \%)$ and 18 years and less for $253(49.7 \%)$. The ages of marriage for females is shown in Fig. 3.

When violence at the household level was queried, there were reports of 415 injuries to women resulting from intimate partner violence, shown in Table 3. A further 85 persons had been injured from someone outside of the household, but not from direct military action. Questions about gender-based violence attacks occurring outside the household were consistently asked by interviewers, and respondents claimed they knew of none.

\section{Employment}

When the informant was asked about employment status, the major categories were $353(29.4 \%)$ with no employment and $442(36.8 \%)$ indicating some part time work (Table 4). For those who said they were employed, this may have reflected a nominal employment status, but perhaps not one that was currently paying wages. When asked who had brought cash into the household in the past 2 months, there were only 304 persons identified

Table 3 Marriages since 2014, and intimate partner violence reported

\begin{tabular}{|c|c|c|c|c|c|c|}
\hline & \multicolumn{2}{|c|}{ East Mosul } & \multicolumn{2}{|c|}{ West Mosul } & \multicolumn{2}{|l|}{ Total } \\
\hline & No. & $\%$ & No. & $\%$ & No. & $\%$ \\
\hline \multicolumn{7}{|c|}{ Sex of the person getting married } \\
\hline Males & 71 & 14.3 & 60 & 18.5 & 131 & 16.0 \\
\hline Females & 424 & 85.7 & 264 & 81.5 & 688 & 84.0 \\
\hline \multicolumn{7}{|c|}{ Age of the person getting married } \\
\hline $10-19$ & 232 & 46.9 & 155 & 47.8 & 387 & 47.3 \\
\hline $20-29$ & 254 & 51.3 & 156 & 48.1 & 410 & 50.1 \\
\hline 30-39 & 9 & 1.8 & 12 & 3.7 & 21 & 2.6 \\
\hline $40-49$ & - & - & - & - & - & - \\
\hline $50-59$ & - & - & 1 & 0.3 & 1 & 0.1 \\
\hline \multicolumn{7}{|c|}{$\begin{array}{l}\text { Has there been any physical violence between husband and wife which } \\
\text { led to injury to the wife since June } 2014 \text { ? }\end{array}$} \\
\hline Yes & 132 & 17.6 & 283 & 62.8 & 415 & 34.5 \\
\hline No & 612 & 81.5 & 168 & 37.3 & 780 & 64.9 \\
\hline Don't know & 7 & 0.9 & - & - & 7 & 0.6 \\
\hline \multicolumn{7}{|c|}{$\begin{array}{l}\text { Has there been any violence between someone in the household and } \\
\text { someone from outside the household which has produced an injury } \\
\text { since June } 2014 \text { ? }\end{array}$} \\
\hline Yes & 80 & 10.7 & 5 & 1.1 & 85 & 7.1 \\
\hline No & 665 & 88.6 & 444 & 98.5 & 1109 & 92.3 \\
\hline Don't know & 6 & 0.8 & 2 & 0.4 & 8 & 0.7 \\
\hline
\end{tabular}

from the 1202 households. In $61.2 \%$ of cases it was the wives who were bringing cash into the households.

\section{Structure and utilities}

The assessment of household living circumstances at the end of the military activities show the difficult living circumstances being experienced (Table 5). Some 308 (41.0\%) dwellings surveyed in east Mosul had no damage; 105 (14.0\%) had major damage or were destroyedforcing households to move. By contrast, in west Mosul only 2 dwellings $(0.4 \%)$ were reported to be without some damage. There were 255 (56.5\%) households which reported major damage to their dwelling, while 98 (21.7\%.) reported their dwelling had been destroyed and they were forced to move. Kerosene and wood were major sources of energy, but wood was the major source of household energy for 310 (59.0\%) households in west Mosul. Only 135 (11.2\%) households reported they had adequate fuel for cooking. Electricity in Mosul was intermittently available to 656 (54.6\%) households, with no households having a regular supply. In west Mosul, 389 (86.3\%) reported no electricity. Water supply was obtained from wells for 1161 (96.6\%) households. With carried water, $99.9 \%$ of flush toilets could be used.

\section{Discussion}

The data from this study reflect the impact on households of the 31-36 months of ISIS control of east and west Mosul, respectively. The damage to lives, the social structure of the communities and the education of children during this period is substantial. The consequences of the fighting to liberate Mosul from ISIS has created further suffering among Mosul households through the damage and destructions of dwellings, further deterioration in utilities, and shortage of cooking fuel.

Because of the fear of indoctrination and radicalization, almost all families kept their children from school. Many feared their older sons would be taken to be fighters during regular ISIS raids on schools [12]. Some children were taught at home, but most were not. This is a greater loss of education years than was previously documented for children from families fleeing the fighting in $\mathrm{Al}$ Anbar in 2015 [13].

In September 2014, the ISIS education bureau revised the curriculum for primary, secondary and university education, adding many religious topics, physical fitness and weaponry training. In addition, it imposed primary school fees of 15,000 dinars (\$US12.60) per month as the Mosul economy worsened. ISIS threatened parents who did not send their children to schools. Teachers, especially women, were threatened with beheading if they did not report for classes [14]. Yet, families did not comply. Children have been traumatized by witnessing scenes of violence and executions of family, relatives and 


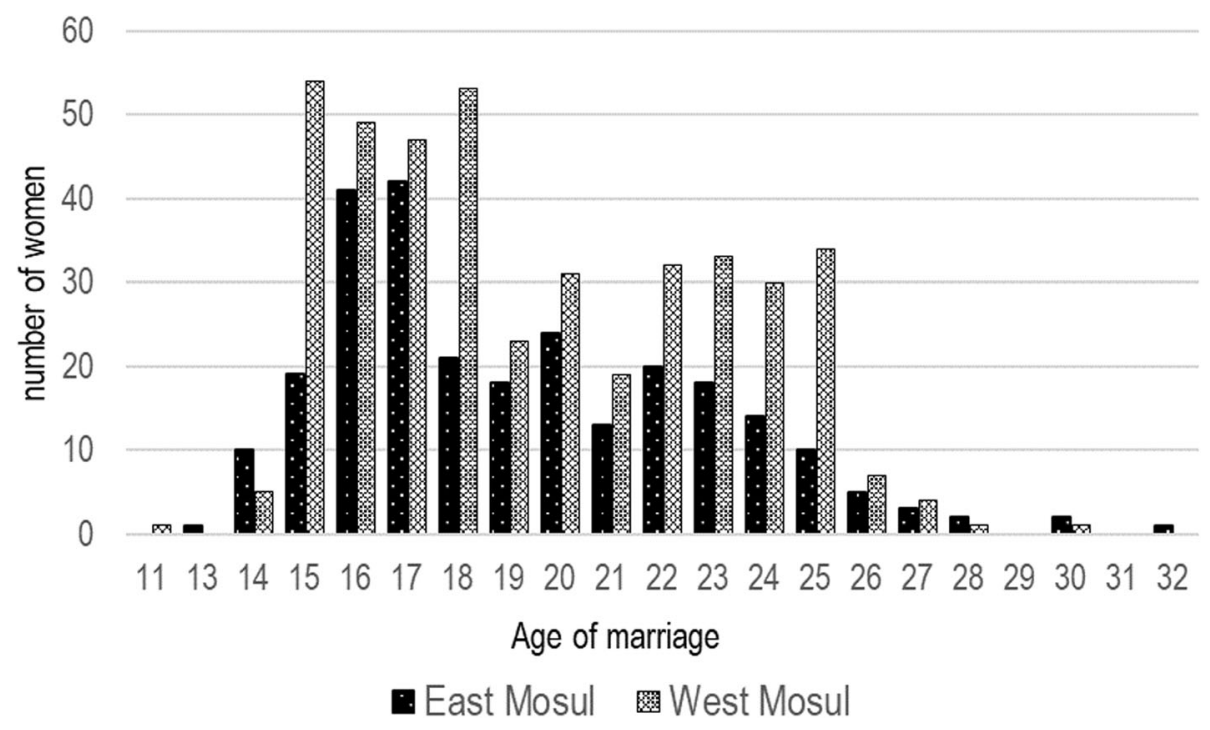

Fig. 3 Age of Marriage for women in east and west Mosul 2014-2017

friends. Many children have lost family members or their entire family [15]. Since liberation, schools have reopened with unpaid teachers volunteering, and with children returning in numbers to recommence their education [16]. Recovering lost years of school will be impossible. Dealing with the psychological trauma from the brutality experienced by children is a great challenge [17]. The absence of education and the emotional trauma of the ISIS years combine to potentially cause considerable difficulties for children as they return to school.

The fear of forced marriages of daughters to ISIS members, especially foreign fighters, drove some residents to flee Mosul with their families. Many of those families remaining arranged marriages among relatives or other

Table 4 Livelihoods at the time of the interviews

\begin{tabular}{|c|c|c|c|c|c|c|}
\hline & \multicolumn{2}{|c|}{ East Mosul } & \multicolumn{2}{|c|}{ West Mosul } & \multicolumn{2}{|l|}{ Total } \\
\hline & No. & $\%$ & No. & $\%$ & No. & $\%$ \\
\hline \multicolumn{7}{|c|}{ Current employment status of head of household ${ }^{a}$} \\
\hline Clerical or office work & 6 & 0.8 & - & - & 6 & 0.5 \\
\hline Manual labor, full time & 70 & 9.3 & 4 & 0.9 & 74 & 6.2 \\
\hline Manual labor, part time & 211 & 28.1 & 10 & 2.2 & 221 & 18.4 \\
\hline Market sales & 131 & 17.4 & - & - & 131 & 10.9 \\
\hline Domestic work & 23 & 3.1 & - & - & 23 & 1.9 \\
\hline Various intermittent casual work & 222 & 29.6 & - & - & 222 & 18.4 \\
\hline No work & 9 & 1.2 & 344 & 76.3 & 353 & 29.4 \\
\hline Retired & 79 & 10.5 & 93 & 20.6 & 172 & 14.3 \\
\hline \multicolumn{7}{|c|}{ Persons earning cash during the past 2 months ${ }^{b}$} \\
\hline Wife & 122 & 62.9 & 64 & 66.0 & 186 & 61.2 \\
\hline Husband & 55 & 28.4 & 20 & 20.6 & 75 & 28.0 \\
\hline Son & 15 & 7.7 & 6 & 6.2 & 21 & 7.6 \\
\hline Daughter & - & - & 1 & 1.0 & 1 & 0.7 \\
\hline Grandmother & 1 & 0.5 & 1 & 1.0 & 2 & 0.7 \\
\hline Grandfather & - & - & 2 & 2.1 & 2 & 0.7 \\
\hline Sibling of household head & 1 & 0.5 & 3 & 3.1 & 4 & 1.3 \\
\hline Households with no cash income & 4684 & 95.3 & 2595 & 96.3 & 7268 & 96.0 \\
\hline
\end{tabular}

${ }^{a}$ Nominal employment status even if not currently being paid

b11 households in east Mosul had 2 persons earning cash; in west Mosul there were no households with more than 1 person 
Table 5 Living circumstances

\begin{tabular}{|c|c|c|c|c|c|c|}
\hline & \multicolumn{2}{|c|}{ East Mosul } & \multicolumn{2}{|c|}{ West Mosul } & \multicolumn{2}{|l|}{ Total } \\
\hline & No. & $\%$ & No. & $\%$ & No. & $\%$ \\
\hline \multicolumn{7}{|l|}{ Damage to house in conflict } \\
\hline None & 308 & 41.0 & 2 & 0.4 & 310 & 25.8 \\
\hline Minor damage & 338 & 45.0 & 96 & 21.3 & 434 & 36.1 \\
\hline Major damage & 77 & 10.3 & 255 & 56.5 & 332 & 27.6 \\
\hline Destroyed and $\mathrm{HH}$ moved & 28 & 3.7 & 98 & 21.7 & 126 & 10.5 \\
\hline \multicolumn{7}{|l|}{ Major source of energy } \\
\hline Kerosene & 439 & 58.5 & 183 & 40.6 & 622 & 51.7 \\
\hline Gas & 2 & 0.3 & 1 & 0.2 & 3 & 0.2 \\
\hline Electricity & - & - & - & - & - & - \\
\hline Wood & 310 & 41.3 & 266 & 59.0 & 576 & 47.9 \\
\hline Other & - & - & 1 & 0.2 & 1 & 0.1 \\
\hline \multicolumn{7}{|l|}{ Adequate fuel for cooking } \\
\hline Yes & 129 & 17.2 & 6 & 1.3 & 135 & 11.2 \\
\hline No & 553 & 73.6 & 443 & 98.2 & 996 & 82.9 \\
\hline Sometimes & 69 & 9.2 & 2 & 0.4 & 71 & 5.9 \\
\hline \multicolumn{7}{|l|}{ Availability of electricity } \\
\hline Have almost all the time & - & - & - & - & - & - \\
\hline Equal amount on and off & 2 & 0.3 & 1 & 0.2 & 3 & 0.3 \\
\hline Mostly off & 595 & 79.2 & 61 & 13.5 & 656 & 54.6 \\
\hline No electricity & 154 & 20.5 & 389 & 86.3 & 543 & 45.2 \\
\hline \multicolumn{7}{|l|}{ Principal source of water } \\
\hline Piped water & - & - & 19 & 4.2 & 19 & 1.6 \\
\hline Tanker & - & - & - & - & - & - \\
\hline Well & 751 & 100.0 & 410 & 90.9 & 1161 & 96.6 \\
\hline River & - & - & 16 & 3.6 & 16 & 1.3 \\
\hline Other & - & - & 6 & 1.3 & 6 & 0.5 \\
\hline \multicolumn{7}{|l|}{ Presence of a working toilet } \\
\hline Yes & 750 & 99.9 & 442 & 98.0 & 1192 & 99.2 \\
\hline No & 1 & 0.1 & 9 & 2.0 & 10 & 0.8 \\
\hline
\end{tabular}

families. After marriage, many couples moved from Mosul where this was possible. This type of "protective" strategy to protect a daughter's honor is described in conflict situations [18]. There were isolated reports of executions in Mosul over refusals of forced marriages to fighters, though overall, forced marriages did not seem to occur to the extent the population had feared [19]. It nevertheless remained a powerful fear and encouraged families to expeditiously marry their daughters, perhaps not always wisely. For Iraq as a whole, Unicef data indicate that 4.6\% of girls under age 15 were married and $24.3 \%$. of girls under age 18 were married [20]. In our survey population, $12.9 \%$ of marriages of women were age 15 and less, and $49.7 \%$ of marriages were for women aged 18 and less. A decrease in age of first marriage among women has been well documented [21, 22]. The reasons for these early marriage during conflict are often a complex mixture of cultural and economic reasons and sometimes were associated with lack of educational and employment options [23]. As the ISIS forces consolidated control of Mosul, young adult males also fled, fearing that if they stayed they could have no social contact with women and would be at risk of ISIS forced recruitment if they remained in Mosul. Marriage was not a protective strategy that worked for adolescent males who were liable to ISIS conscription regardless of marital status.

There were $34.5 \%$ of respondents (women) who reported intimate partner violence (IPV) leading to injury, which seems high, even by the reported levels in the Middle East [24, 25]. High prevalence of IPV among refugees and conflict-affected populations have been well documented, and are perhaps related to the economic, psychological and financial stresses of their situation [26-28]. These were all stresses present in Mosul. It is likely that these stresses will continue during what will be a difficult and prolonged recovery of the city.

Extensive destruction of housing affected all parts of Mosul. In east Mosul, 14.0\% of houses sustained severe damage, with $3.7 \%$ uninhabitable. Almost all of this happened during the military liberation campaign. Even after the largely destroyed neighborhoods in west Mosul were dropped from the sampling frame, there were still $78.2 \%$ of houses which had sustained major damage, with about a third where the damage was so great that the household had been forced to move. The heavy use of artillery, IRAMs and airstrikes were reportedly responsible for much of the damage. However, airstrikes caused a disproportionate share of the human and infrastructural losses, particularly in west Mosul [29]. Some social and commercial life has returned to Mosul, especially in the less damaged east part of the city. The costs of rebuilding the entire city to its former state are in the billions of dollars and will require many years [30].

Water had been intermittently available during the ISIS occupation, though water treatment had faltered within the first year of the ISIS occupation [2, 31]. During the fighting in late 2017, a pipeline was hit which cut water to $40 \%$ of the city's population [32]. Hand dug wells provided almost all water to households at the time of this survey [33]. Although households reported functioning flush toilets, these were functioning with water carried by hand. Electricity supplies had been steadily deteriorating for some time, but at the time of the survey it was mostly off, making it not possible to operate fans and air coolers when the temperature reached $45^{\circ} \mathrm{C}$ [2]. During ISIS control the major energy source was kerosene. During the military liberation campaign, wood because a major source of fuel, particularly in west Mosul. Insufficient fuel for cooking was reported for most households, particularly in west Mosul [34]. 


\section{Limitations}

There are many limitations to a study such as this conducted immediately following a major urban conflict. The sampling frame was initially based on pre-ISIS population distribution living in discrete administrative units or neighborhoods. While these neighborhoods each had approximately the same number of households before the ISIS occupation, the household numbers may have changed during the events after June 2014, potentially creating a sampling bias. This may have reduced representativeness, particularly in west Mosul, where many destroyed neighborhoods necessitated a substantial revision to the sampling frame. Still, after revisions to the sampling frame, two clusters had to be replaced, one because of insecurity, and a second because almost all of the remaining inhabitants had left. Even in the neighborhoods surveyed, many houses in the selected clusters were destroyed or deserted, particularly in west Mosul, creating a substantial survivor bias. As extended families tend to live in adjacent households, bias from clustering is likely.

\section{Conclusions}

Data in this paper reflect the substantial impact ISIS occupation had on the city followed by the consequences of military action to destroy ISIS, particularly affecting west Mosul. The early marriage and the high prevalence of IPV, damage to dwellings, and households surviving without water and electricity are some of the stresses experienced. High unemployment, especially among males, was a further stress. Several years of education which were lost for students from grade school through to university that are difficult to replace. The costs of reconstructing Mosul and its economy will be high. The repair to lives damaged and destroyed by ISIS and recovery of lost opportunities will never be possible.

\section{Acknowledgements \\ Our deepest appreciation and admiration go to the four interviewers who visited the 1,202 households in the devastated remains of their city. Their physical and emotional stamina was phenomenal. Appreciation goes to others in the Iraq team who helped so much to make this study possible, and who wish to remain unidentified.}

\section{Data access}

The data set and materials reported in this study are available from the corresponding author on reasonable requests.

\section{Authors' contributions \\ $\mathrm{RL}$ and $\mathrm{GB}$ conceived the study. $\mathrm{RL}$ recruited and trained interviewers and oversaw implementation. VC participated in the study design, managed the cluster sampling and data analysis. All authors had access to the data. GB wrote the first draft of the paper, and all authors contributed to the final paper. The views expressed are those of the authors and do not necessarily reflect the views of the United Nations with whom VC is employed. All authors read and approved the final manuscript.}

\section{Ethics approval and consent to participate}

The study received approval from the Scientific and Technical Committee of Al Mustansiriya University. The Institutional Review Board at Johns Hopkins
Bloomberg School of Public Health declared the analysis of data without personal identifiers as exempt. All participants provided verbal consent and were free to stop the interview at any time. No compensation was provided for participation. All authors read and approved the final manuscript.

\section{Competing interests}

The authors declare that they have no competing interests.

\section{Publisher's Note}

Springer Nature remains neutral with regard to jurisdictional claims in published maps and institutional affiliations.

\section{Author details}

${ }^{1}$ Department of Community Medicine, Al Mustansiriya University, Baghdad, Iraq. ${ }^{2}$ Demographic and Social Statistics Section, United Nations Economic and Social Commission for Western Asia, Beirut, Lebanon. ${ }^{3}$ Department of International Health, The Johns Hopkins Bloomberg School of Public Health, 615 N Wolfe Street, Baltimore, MD 21205, USA.

Received: 12 November 2017 Accepted: 10 May 2018

Published online: 01 August 2018

References

1. Al-Salh S, Arango T. Sunni militants drive Iraqi Army out of Mosul. New York Times. 2014;

2. UN Habitat. City Profile of Mosul, Iraq. http://reliefweb.int/sites/reliefweb.int/ files/resources/UN-Habitat_MosulCityProfile_V5.pdf (accessed Aug. 20,2017).

3. White R. The Secret Eye Inside Mosul. New Yorker, 2016, DOl: https://doi. org/10.1016/j.etap.2016.08.015.

4. Nazish K. Life under Islamic state rule in Mosul one of constant fear. USA today, 2015.

5. Cunningham E. ISIS Imposes a reign of fear in Iraq hospitals. Washington post, 2104.

6. Verini J. The living and the dead, New York Times, 2017. https://www. nytimes.com/interactive/2017/07/19/magazine/mosul-battle-against-isis.html (accessed Aug. 14, 2017)

7. Paletta D, Entous A. Militants in Iraq siphon state pay. Wall Street J. 2015;

8. Iraqi Institution for Development. Education in Mosul under the Islamic State (ISIS). 2015-2016. http://www.campaignforeducation.org/docs/reports/ ISIS\%20in\%20lraq_2015\%20-\%202016\%20Education\%20in\%20Mosul_. English_FINAL.pdf (accessed Sept. 25, 2017), DOl: https://doi.org/10.1016/j. neuroimage.2014.12.005.

9. Spencer R. Islamic state issues new school curriculum in Iraq. The Telegraph Sept 16, 2014. http://www.telegraph.co.uk/news/worldnews/middleeast/ iraq/11099882/Islamic-State-issues-new-school-curriculum-in-Iraq.html (accessed Sept. 30, 2017).

10. BBC News. Major general: battle for Mosul is 'toughest since WWII', quoting Major General Rupert Jones, deputy commander, Combined Joint Task Force 2017. http://www.bbc.com/news/av/world-40409046/major-generalbattle-for-mosul-is-toughest-since-wwii (accessed Jan. 5, 2018).

11. Lafta R, Al-Shatari S, Cherewick M, Galway L, Mock C, Hagopian A, Flaxman A, Takaro T, Greer A, Kushner A, Burnham G. Injuries, death, and disability associated with 11 years of conflict in Baghdad, Iraq: a randomized household cluster survey. PLoS One. 2015 Aug 7;10(8):e0131834. https://doi. org/10.1371/journal.pone.0131834.

12. Cockburn, P. Refugees from Isis tell of fears of forced marriages. The Independent (UK). 2017. http://www.independent.co.uk/news/world/middleeast/refugees-from-isis-tell-of-fears-of-forced-marriages-10109823.html (accessed Sept. 22, 2017), DOI: https://doi.org/10.1016/j.jpsycho.2017.11.017.

13. Lafta R, Aflouk NA, Dhiala S, Lyles E, Burnham G. Needs of internally displaced women and children in Baghdad, Karbala, and Kirkuk, Iraq. PLOS currents Disasters. 2016:

14. Mosul Eye, 2015. Mosul Eye Report Education in Mosul Under ISIL's Rule "Soft Resistance and Civil Disobedience". https://mosuleye.files.wordpress. com/2015/12/mosul-eye-education-under-isil.pdf (accessed Sept. 27, 2017), DOl: https://doi.org/10.1212/WNL.0000000000001267.

15. Briggs B. 60,000 children back at school in West Mosul but others are traumatised and hiding. Theirworld, July 25, 2017. http://theirworld.org/news/ thousands-of-mosul-children-back-at-school-but-many-others-traumatised (accessed Sept. 17, 2017), DOl: https://doi.org/10.18294/sc.2017.1152. 
16. Hennessy-Fiske M. The teachers are unpaid and danger is ever present, but Mosul's schools are reopening. Los Angeles Times 2017. http://www.latimes. com/world/middleeast/la-fg-mosul-schools-2017-story.html (accessed Sept. 22, 2017).

17. Save the Children, UK. Mosul's Children Mentally Scarred by Brutal Conflict. http://www.savethechildren.org.uk/2017-07/mosul\%E2\%80\%99s-childrenmentally-scarred-brutal-conflict (accessed Sept 27, 2017), DOI: https://doi. org/10.17226/24911.

18. Hutchinson A, Waterhouse P, March-McDonald J, Neal S, Ingham R. Understanding early marriage and transactional sex in the context of armed conflict: protection at a price. Int Perspect Sex Reprod Health. 2016;42:45-9. https://doi.org/10.1363/42e0416.

19. Sonawane V. ISIS Executes at least 250 women for refusing 'temporary marriage' in Iraq's Mosul. International business Times, 2016. http://www. ibtimes.com/isis-executes-least-250-women-refusing-temporary-marriageiraqs-mosul-2357113 (accessed Sept. 27, 2017), DOl: https://doi.org/10.1016/ j.jimyco.2016.09.005.

20. Unicef Iraq. Statistics. https://www.unicef.org/infobycountry/iraq_statistics. html (accessed Sept. 29, 2017).

21. Cherrin Z, Cuesta JG, Rodriguez-Llanes J, Guha-Sapir D. Early marriage and barriers to contraception among Syrian refugee women in Lebanon: a qualitative study. Int J Environ Res Public Health. 2007;17:836. https://doi. org/10.3390/ijerph14080836.

22. Schlecht J, Rowley E, Babirye J. Early relationships and marriage in conflict and post-conflict settings: vulnerability of youth in Uganda. Reproductive Health Matters. 2013;21:234-42. https://doi.org/10.1016/S09688080(13)41710-X.

23. Kottegoda S, Kumundini S, Emmanuel S. Reproductive health concerns in six conflict-affected areas of Sri Lanka. Reprod Health Matters. 2008;16:7582. https://doi.org/10.1016/S0968-8080(08)31359-7.

24. Maziak W, Asfar T. Physical abuse in low-income women in Aleppo, Syria. Health Care for Women International. 2003;24:313-26. https://doi.org/10. 1080/07399330390191689.

25. Clark CJ, Bloom DE, Hill AG, Silverman JG. Prevalence estimate of intimate partner violence in Jordan. East Mediterr Health J. 2009;15:880-9.

26. Al-Modallal H, Abu Zayed I, Abujilban S, Shehab T, Atoum M. Prevalence of intimate partner violence among women visiting health care centers in Palestine refugee camps in Jordan. Health Care Women Int. 2014;36:137-48.

27. Wirtz AL, Pham K, Glass N, Loochkartt S, Kidane T, Cuspoca D, Rubenstein LS, Singh 7, Vu A. Gender-based violence in conflict and displacement: qualitative findings from displaced women in Colombia. Confl Health. 2014 doi: https://doi.org/10.1186/1752-1505-8-10.

28. Ward J, Vann B. Gender-based violence in refugee settings. Lancet. 2002; 360(Suppl):s13-4.

29. Oakford S. Mosul's capture sees ISIS vanquished - but at a terrible cost. Airwars July 1, 2017. https://airwars.org/news/mosuls-capture-sees-isilvanquished-but-at-a-terrible-cost/ (accessed Sept. 28 2017).

30. Aboulenein A. Five years, billions of dollars needed to rebuild Mosul: officials. Reuters May 3 2017. https:/www.reuters.com/article/us-mideastcrisis-iraq-mosul-reconstruct/five-years-billions-of-dollars-needed-to-rebuildmosul-officials-idUSKBN17Z198 (accessed Sept. 28, 2017).

31. BBC. Mosul diaries: Poisoned by water. 2014. http://www.bbc.com/news/ world-middle-east-29600573 (accessed Sept. 28, 2017).

32. Al Jazeera. Water supply cut off for half of Mosul. 2016. http://www. aljazeera.com/news/2016/11/water-supply-cut-iraq-mosul-161129202802305. html (accessed Sept. 26, 3017).

33. Zucchino D, Solomon B. Stuck without water in Mosul, Neighbors Find a Way New York Times Feb 16, 2017. https://www.nytimes.com/2017/02/16/ world/middleeast/stuck-without-water-in-mosul-neighbors-find-a-way. html?_r=0 (accessed Sept. 30, 2017).

34. Neurink J. Children survive 'Islamic State' hungry and traumatized. Deustche Welle, 2017. http://www.dw.com/en/children-survive-islamic-state-hungryand-traumatized/a-39824141 (accessed Sept. 25, 2017).

\section{Ready to submit your research? Choose BMC and benefit from:}

- fast, convenient online submission

- thorough peer review by experienced researchers in your field

- rapid publication on acceptance

- support for research data, including large and complex data types

- gold Open Access which fosters wider collaboration and increased citations

- maximum visibility for your research: over $100 \mathrm{M}$ website views per year

At BMC, research is always in progress.

Learn more biomedcentral.com/submissions 